\title{
Bali Tamás ezredes:
}

\section{FEGYVERNEMI KULTÚRAVÁLTÁS A H145M HELIKOPTER HAZAI RENDSZERBE ÁLLÍTÁSÁVAL}

\author{
DOI: $\underline{10.35926 / \mathrm{HSZ} .2021 .1 .1}$
}

ÖSSZEFOGLALÓ: A Magyar Honvédség vezetése évtizedek óta foglalkozik a szovjet/orosz fegyverzetre épülő haderő megújitásának lehetséges irányaival. A megújitás messze túlmutat az országvédelmi követelményeken, mert figyelembe kell venni gazdasági, politikai és védelempolitikai tényezőket is. Ebben a különböző irányultságú érdekektöl vezérelt környezetben kellett megtalálni azt a hosszú távú megoldást, mely fenntartható módon egyaránt biztosítja a hazai védelmi igények kielégítését és a szövetségesi elvárásoknak való megfelelést. A H145M típusú könnyü helikopter hazai rendszeresítésével egy olyan korszerü technológiát képviselő légi jármü jelent meg a Magyar Honvédség kötelékében, amely kultúraváltást eredményezett a forgószárnyas erőknél. A szerző tanulmányában ennek részleteit mutatja be.

KULCSSZAVAK: H145M, helikopter, digitális technológia, Magyar Honvédség

\section{BEVEZETÉS}

Vissza kell tekinteni a múltba ahhoz, hogy érthető legyen a kultúraváltás fogalma a magyar forgószárnyas erökön belül. Meg kell vizsgálni azt, hogy honnan indultunk és hová érkeztünk.

Megítélésem szerint amikor a gyökereinkre tekintünk vissza, akkor leginkább azt az időszakot kell vizsgálnunk, amikor a magyar haderő még a Varsói Szerződés (VSZ) keretein belül tevékenykedett. Fontos ez, hiszen az a korszak minden tekintetben rányomta bélyegét az akkori és részben a mai haderő technikai felszereltségére, müveleti eljárásrendjeire. Az akkori magyar hadseregnek egyrészt az országvédelmi feladatait kellett teljesítenie, másrészt helyt kellett állnia a VSZ szövetségesi keretén belül is. Folyamatosan késznek kellett lennie a nyugati irányból a Szovjetunió elleni, azaz keleti irányba történő ellenséges előrenyomulás megállítására, de legalábbis lassítására. Feladata volt a behatoló NATO-erők feltartóztatása a területén addig, míg a katonai értelemben messze potensebb szovjet haderő a harcászati területre fel nem sorakozik vagy sorakozott volna. Mindemellett volt egy - véleményem szerint teljesíthetetlen - további szövetségesi feladata, miszerint képesnek kellett volna lennie támadó müveletekre a délnyugati hadszíntéren.

Kijelenthető, hogy Magyarország ahogyan ma, úgy a hidegháború időszakában is a geostratégiai elhelyezkedéséből adódóan gyakorlatilag a NATO és az akkori Szovjetunió, illetve a mostani Oroszország ütközőzónájában helyezkedett el. De nemcsak önmagában, hanem vele együtt a Német Demokratikus Köztársaság, Lengyelország, Csehszlovákia, Románia és Bulgária is.

Ez a stratégiai státus Magyarország számára katonai szempontból azt eredményezte, hogy hadereje meghatározóan szovjet haditechnikai eszközökkel volt felszerelve. Ezek az eszközök - szintén hazánk stratégiai jelentőségű feladatrendszeréből adódóan - magas 
hadrafoghatósági szinttel rendelkeztek, viszont a harcászati képességeik korlátozottak voltak. Nyilvánvaló okok miatt a hadviselés hangsúlya az önvédelmen volt, kevésbé a támadáson. Ez a kiképzés területén is megmutatkozott. Szűken a forgószárnyas képzésre koncentrálva kijelenthető, hogy az azt szabályzó, számunkra biztosított szovjet (de magyarra fordított) kiképzési utasítások ${ }^{1,2}$ nem tartalmazták a támadó müveletek támogatásához szükséges harcászati eljárásokat. Mindezért az akkoriban a csapatoknál folyó harckiképzést hiányosnak kell tekinteni. A kiképzési hiányosság további összetevője az is, hogy a helikoptervezetők képzése a Szovjetunióban döntően az alapjártasságok és -készségek kialakítására koncentrált, gyakorlatilag teljes mértékben nélkülözte a harcászati képzést.

Mindez azonban nem okozott égető problémát addig, míg a helikopterbázis harci és szállítóhelikopteres katonái (helikoptervezetők, fedélzeti technikusok és ajtólövészek) oktatókként meg nem jelentek az afganisztáni hadszíntéren. ${ }^{3}$ Ott, ahol olyan támadó jellegü eljárások oktatását várta el tölünk a szövetségeseinken túl az afgán hadvezetés, melyekkel sikeresen vehették fel a harcot a kormányellenes erőkkel. A feladatot - leginkább az amerikai erőkkel együttmüködve - megoldottuk, de ott már kontrasztosan jelentkeztek a hiányosságok. A tanulási folyamat eredményeként mind a harci, mind pedig a szállítóhelikopteres kiképzési utasításokat kiegészítettük, a szolnoki harckiképzés átalakult.

Katonáinknak Kabulban és Síndandban lehetőségük nyílt azokkal az amúgy fizetés nélküli szabadságon az országban tartózkodó orosz hivatásos katonákkal egyeztetniük, akik a NATO-erők által Afganisztánnak vásárolt Mi-24 és Mi-17 helikoptereket az amerikai fél által bérelt szolgáltatás útján üzemeltették. Ök lehetőséget adtak arra, hogy megismerjük azokat a kiképzési utasításokat is, amelyeket a magyar haderő részére a szovjet haditechnikai eszközök rendszeresítésének idején nem adtak át, pontosabban azokat, melyeket kifejezetten a támadó és manőverező harc megvívására dolgoztak ki.

\section{A KÖZELMÚLT ESEMÉNYEINEK HATÁSA A FORGÓSZÁRNYAS FLOTTA ÁTALAKÍTÁSÁRA}

1999. március 12., Magyarország NATO-csatlakozása óta új helyzet alakult ki. Abban az időben, a balkáni válság tetőpontján hazánk újból kiemelt stratégiai helyzetbe került. Alig néhány nappal csatlakozását követően lehetősége nyílt szövetségesi elkötelezettségének bizonyítására, miután a NATO a koszovói válság nyomán március 24-én elindította jugoszláviai légi müveletét, amelyben Magyarország sokoldalúan támogatta ${ }^{4}$ a müveletben részt vevő NATO-erőket. A NATO-taggá válással azonban az akkori magyar katonai vezetés nehéz örökséget kapott: keleti eredetű fegyverzet és korlátozott/hiányos kiképzettség birtokában kellett megfelelnie egy más, nyugati szemléletü katonai gondolkodás elvárásainak.

\footnotetext{
Re/1320 Mi-8/17 Helikopter Harckiképzési Szakutasítás. Honvédelmi Minisztérium, 1981.

2 Re/390 Mi-24D Helikopter Harckiképzési Szakutasítása. Honvédelmi Minisztérium, 1977.

3 Az MH Mi-35 Légi Kiképzés Támogató Csoport 2010. április 9-től 2013. április 30-ig Kabulban támogatta a NATO Afganisztáni Kiképző Misszióját egy olyan 10 fős helikoptervezetői, illetve repülö-müszaki kiképzőcsoporttal, melynek feladata az afgán légierő harci helikopteres erőinek képzése volt. Emellett az MH Mi-17 Légi Tanácsadó Csoport 2011. augusztus 24-től 2014. október 1-jéig a Síndand Légibázison váltásonként 11 fővel hajtotta végre az afgán szállítóhelikopter-fedélzeti személyzettagok, illetve afgán repülő-müszakiak kiképzési feladatait.

4 A magyarországi támogatás lényegében a légtere biztosításában, illetve a repülöbázisainak használatba adásával valósult meg.
} 
Nyilvánvalóvá vált, hogy a helyzet fenntarthatatlan. A volt szovjet, illetve orosz haditechnikai eszközök rendszerben tartása a NATO-csatlakozást követően egyre nagyobb nehézségekbe ütközött. Az üzemeltetéshez szükséges logisztikai folyamatok akadozni kezdtek, és nemcsak a helikopterek, hanem az összes haditechnikai eszköz fenntartása egyfajta logisztikai rémálommá vált. A hadrafoghatóság fenntartása az alkatrész-utánpótlás akadozása miatt lehetetlenné vált. Érthető módon az oroszok a továbbiakban már nem akarták támogatni az ellenük irányuló magyar haderő fenntartását.

Az oroszokkal kötött fenntartási szerződések már nem voltak előnyösek számunkra. Az alkatrészek leszállítására tőlük kapott határidők végletesen megnyúltak, például a rendszerben lévő légi járművek fenntartásához szükséges eszközök beszállításai 180 napos határidővel teljesültek. Nyilvánvaló volt, hogy ez már rövid távon is fenntarthatatlan, ezért nyugati irányba kell fordulni, és meg kell találni azokat a lehetőségeket/megoldásokat, amelyekkel ki lehet váltani az akkori orosz, amúgy is elöregedett haditechnikai eszközparkot.

Érthető módon a politikai érdekszféra átalakulása kényszerítette ki a haderő megújításának igényét, melynek kapcsán a helikopterek tekintetében gyakorlatilag 2000-től megkezdődött a flottaváltás előkészítése. Az egyeztetések után három, egymást követő esetleges beszerzési irány körvonalazódott.

Az időben első projekt megvalósulása esetén - amerikai felajánlásból - viszonylag nagy létszámú UH-1 helikopterflottát lehetett volna kialakítani. Bár a helikopterek beszerzése nem járt volna költségvonzattal, de fenntartásuk nagyon komoly ráfordítást kívánt volna meg, melynek csupán csak az egyik összetevője lett volna az, hogy a helikoptereket periodikus karbantartásokra vissza kellett volna szállítani az amerikai kontinensre. Emellett természetesen az egész repülő-müszaki kiszolgáló hátteret le kellett volna cserélni az amerikai rendszerre.

A tervezett helikopterflotta borsos üzemeltetési költségeit kritizáló hangok mellett megjelentek a gépek életkorával kapcsolatos fenntartások is, konkrétan: mi indokolja, hogy lecseréljük a közel 40 éves, kiépült infrastruktúrájával rendelkező és bejáratott helikopterflottánkat egy ugyanolyan idős, csak kisebb képességekkel rendelkező másikra? Mivel a gazdasági jellegű kételyek mellett megjelentek a szakmaiak is, így az amúgy számunkra felajánlott, valóban elöregedett technológiát képviselő UH-1-esek rendszeresítéséről megszakadtak a tárgyalások.

Ezután kezdett a honvédelmi tárca az AgustaWestland projekttel foglalkozni, amelyen belül a minisztérium elörehaladott tárgyalásokat folytatott az olasz féllel az AW109 könnyü és az AW139 közepes szállítóhelikopterek beszerzésével kapcsolatban. A beszerzési program a megvalósulás határán bukott meg, mivel az AgustaWestland - ma Leonardo - vezetésével kapcsolatban korrupciós vádak merültek fel egy korábbi indiai gépeladás kapcsán. Ez a projekt a továbbiakban politikailag vált felvállalhatatlanná.

Időben a harmadik lehetséges beszerzési irányként merült fel az amerikai Sikorsky cég európai, azaz lengyelországi üzemében gyártott S-70i típus rendszeresítése. Annak az UH-60 Black Hawknak a nemzetközi piacra gyártott változata, amely nagyon komoly katonai múlttal rendelkezik, amely már több hadszíntéren bizonyított. Az elhúzódó tárgyalások idején - annak érdekében, hogy a hazai forgószárnyas képesség ne szünjön meg - a Mi-17 és a Mi-24 helikopterek nagyjavításon estek át, két Mi-8 helikopter pedig beszerzésre került. A nagymérvü ráfordítás megszüntette a döntéskényszert, és ennek hatására a tárgyalások e projekt tekintetében is megszakadtak. 


\section{A JELEN DÖNTÉSEI, MELYEK HOSSZÚ TÁVON HATÁROZZÁK MEG A JÖVÖT}

Nyilvánvaló, hogy egy nagymérvü fegyverzeti beszerzéssel kapcsolatos döntést politikai, gazdasági, illetve védelempolitika érdekek/összetevők határoznak meg. Annál figyelembe kell venni az ország gazdasági lehetőségeit, a politikai és a stratégiai kapcsolatrendszerét, függőségeit, politikai irányultságát, a döntéssel megszerezhető politikai és gazdasági elönyöket - és persze hátrányokat.

Magyarország számára - az EU tagállamaként - kézenfekvőnek kell lennie annak, hogy elsősorban az Unió országaiban gyártott eszközök beszerzését vizsgálja meg, támogatva ezzel az uniós fejlesztéseket és gazdaságot, illetve így is erősítve saját uniós tárgyalási pozícióit. Ezt természetszerüleg nem nézik jó szemmel azok a világgazdaságot amúgy is meghatározó nagyhatalmak, amelyek komoly fegyvergyártási kapacitással rendelkeznek, illetve érdekükben áll a velük gazdasági versenyben lévő Európai Unió gyengítése. Ebben az esetben megtörténhet, hogy e nagyhatalmak diplomáciai és gazdasági eszközökkel kényszerítik Magyarországot az ő eszközeik beszerzésére. Ugyanakkor, ha a magyar politikai és katonai vezetés az Európai Unión kívüli haditechnikai eszközök beszerzését irányozza elő, akkor az Unió szervezete joggal kérdezheti azt meg, hogy a kontinens szívében miért fordulunk el Európától. Egy ilyen döntés olyan diplomáciai hátrányokat és gazdasági szankciókat eredményezhet, melyek hosszú távon hátrányosan érinthetik országunkat. Ebben a helyzetben kell meghozni a salamoni döntést.

A problémát a Zrínyi 2026 Honvédelmi és Haderőfejlesztési Program ${ }^{5}$ 2016. december 20-i bejelentése oldotta fel. Ez a program - ha csak szüken a légierő haderőnemet tekintjük - nagyon komoly képességnövelö beszerzéseket tett lehetővé. Megteremtette a hadászati szintủ légi személyszállítások lehetőségeit az Airbus A319 és Dassault Falcon 7X repülőgépekkel, illetve biztosította a már elöregedett Jak-52 kiváltását a Zlin Z242L és a Zlin Z143LSi könnyü kiképző repülőgépekkel.

A forgószárnyasok tekintetében e programon belül jelenik meg az Airbus H145M és az Airbus H225M típusú helikopterek beszerzése.

Az Airbus cég által gyártott 20 db H145M, azaz katonai (Military) változatú könnyü többcélú helikopterek beszerzésére vonatkozó szerződést 2018. június 29-én írták alá. ${ }^{6}$ Fél év múlva, 2018. december 14-én született meg a végleges döntés, illetve került aláírásra a szerződés 16 db Airbus H225M közepes szállítóhelikopter beszerzéséröl. ${ }^{7}$ Történelmi jelentőségű döntés volt ez a helikopteres erők életében, hiszen egy 18 évet felölelő hosszú munkát zártak le a szerződések aláírásával.

Mindezekkel összhangban, az első két darab H145M helikopter 2019. november 18-án meg is érkezett az MH 86. Szolnok Helikopter Bázis telephelyére.

5 Simicskó István, akkori honvédelmi miniszter, meghirdette a Zrínyi 2026 elnevezésủ honvédelmi-haderőfejlesztési programot, melynek célja a Magyar Honvédség felfelé ívelő pályára állítása a hadfelszerelés megújításával. A program fejlesztési tervei között szerepel még az önkéntes tartalékos rendszer újjászervezése, a Honvédelmi Sportszövetség elindítása. Simicskó: indul a Zrínyi 2026 program. BOON, 2016. 12. 20. https://boon.hu/helyikozelet/simicsko-indul-a-zrinyi-2026-program-2615932/ (Letöltés időpontja: 2020. 10. 30.)

6 Hungary orders 20 H145Ms. Airbus Media, 29. 06. 2018. https://www.airbus.com/newsroom/press-releases/ en/2018/06/hungary-orders-20-h145ms-html (Letöltés időpontja: 2020. 10. 05.)

7 Hungary orders 16 H225M multi-role helicopters. Airbus Media, 14. 12. 2018. https://www.airbus.com/newsroom/ press-releases/en/2018/12/hungary-orders-16-h225m-multi-role-helicopters.html (Letöltés időpontja: 2020. 10. 05.) 


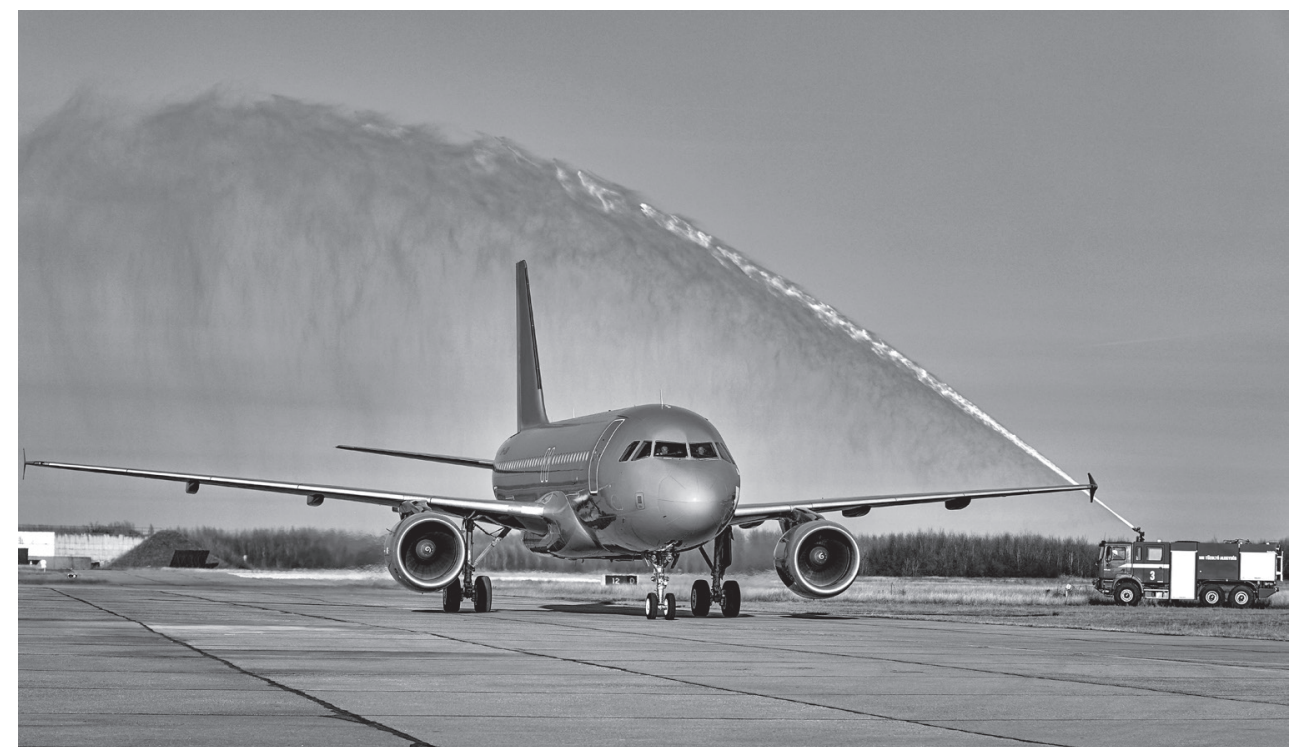

1. kép Az A319 repülögépekkel megújult a légi szállitóképesség

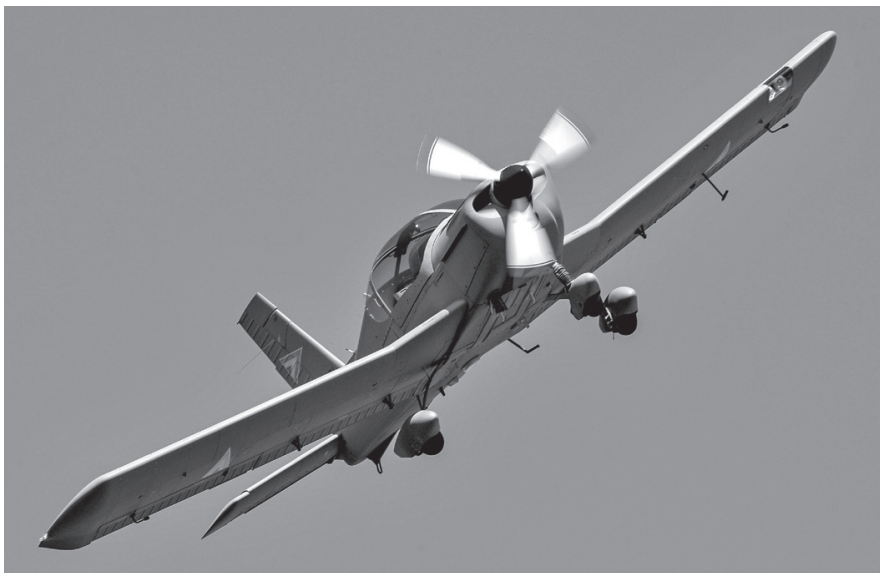

2. kép A leendö pilóták felkészitését szolgáló Zlin típusú kiképzö repülőgép

$\mathrm{Na}$ de mi is érkezett ezekkel a helikopterekkel a Magyar Honvédséghez, ezen belül pedig a légierő helikopteres erőihez? Felmerült az a kérdés is, hogy vajon készen álltunk-e egyáltalán ezeknek a helikoptereknek a rendszerbe állítására, vajon a humán erőforrásunk megfelelő tudással rendelkezik-e a helikopterek üzemeltetéséhez, vagy a helikopterbázis infrastruktúrája, de akár a Magyar Honvédség infrastruktúrája megfelelö-e arra, hogy ezeknek a helikoptereknek az elöírt földi és légi üzemeltetését biztosítani tudjuk? Egyáltalán a helikopterbázis szervezeti felépítése vagy maga a Magyar Honvédség logisztikai rendszere biztosítja-e a mindennapi együttmüködést a gyártóval?

Ha például csak a humán erőforrásra gondolunk, akkor - az elmúlt közel egy év tapasztalataira építve - kijelenthetjük, hogy az angolnyelv-tudás önmagában nem elegendő egy merőben új rendszer elsajátítására. Mind a repülö-hajózó, mind pedig a repülö-müszaki tudás felépítése komoly nehézségekbe ütközött. 


\section{A H145M HELIKOPTER RENDSZERESÍTÉSÉNEK HOZADÉKAI}

Mindenekelőtt talán az infrastrukturális kérdésekkel érdemes foglalkozni. A szovjet/orosz helikopterek nem igényelnek fedett tárolási kapacitást, mert azokat a -50 és a $+50{ }^{\circ} \mathrm{C}$ közötti hőmérsékleti körülmények közötti üzemeltetésre tervezték és építették. ${ }^{8,9}$ Szerkezeti kialakítása egy esetleges jégesőnek is ellenáll, de döntően analóg müszerezettsége következtében akár egy villámcsapás esetén is tovább üzemeltethető. Ezzel ellentétben a digitális rendszerek/ számítógépek által müködtetett H145M tárolása elképzelhetetlen hangárak nélkül.

Bár a gyár nem hangsúlyozza a fedett tárolás szükségességét, mégis a világon jelenleg üzemeltetett összes H145 helikopter hangárakban van elhelyezve - a gyár kiképző helikopterei is Ingolstadtban. Teszik ezt azért, mert a fedélzeti számítógépeknek nem tesz jót, ha például a téli időszakban napi szinten fagy meg és olvad ki annak chipje, nyáron pedig a kiterjedt fülkeplexi felülete miatt az állóhelyen - amikor a fülke belső hőmérséklete $50{ }^{\circ} \mathrm{C}$ fölé emelkedik - szintén naponta túlhevül. Emiatt elkerülhetetlenné vált hangárak építése a helikopterbázison.

A helikopterek törzsszerkezetének üvegszálas (kompozit-), alumínium- és kismértékben kevlárborításai, illetve a kompozitalapú forgószárnylapátok okozták a következő megoldandó problémát. Ezek az anyagok - a kevlár kivételével - külső behatásra maradandó sérülést szenvednek el. Ez azt jelenti, hogy ha például a forgószárny felkap a földfelszínröl egy követ, akkor az megütheti a törzset vagy magát a forgószárnyat, melynek hatására azokon biztosan maradandó sérülés keletkezik. Ez azt eredményezte, hogy át kellett értékelni az eddigi üzemeltetési rendet. Az eddig kavicsosan málló állóhelyeket és gurulóutakat a továbbiakban már nem volt elegendő seprüs kocsikkal letisztítani a repülések előtt, azokra új, darabos szennyeződéstől mentes felületet kellett felhordani. Ez azért is fontos volt, mert a H145M-nek csúszótalpai vannak, így relatívan nagy távolságokra kell vontatni a tárolási helytől a felszállási helyéig. A vontatóeszköz azonban - a kis kerékátmérője miatt - csak akadálymentes, sima felületen alkalmazható.

A helikopterek karbantartása egy újabb megoldásra váró problémát vetett fel. A H145M időszakos karbantartásai, illetve szükségszerü javításai a gyárral közösen, csaknem online módon valósulnak meg. A folyamatosan frissülö karbantartási kézikönyveket, amelyekben az elvégzendő munkapontok megjelennek, valamint a helikopter szoftverfrissítéseit a gyár korlátozott hozzáférésü weboldalára töltik fel. A repülö-müszaki szakembereink a karbantartás alatt folyamatos kapcsolatban vannak a gyár szakembereivel, az interneten böngészik az elvégzendő feladatokat és sorrendiségüket, valamint onnan töltik fel a helikopterre a rendszerfrissítéseket. Mindezek elkerülhetetlenné tették azt, hogy az eddigi karbantartó hangárakba megfelelő sávszélességü internethálózat épüljön ki, mellyel együtt meg kellett újítani a hangárak fütés- és szellőzőrendszerét. Létre kellett hozni a 21. századnak megfelelő munkakörülményeket.

Ezek után a logisztikai kérdések. A helikopterbázis szervezeti felépítésének tekintetében egy olyan új, eddig a Magyar Honvédségnél nem ismert szervezeti elemet $\left(\mathrm{CAMO}^{10}\right)$ kellett kiépíteni, amely biztosítja a folyamatos légi alkalmasságot. A CAMO feladata a H145Mflotta folyamatos üzemképességének biztosítása a helikopterekben lévő repülési időkkel való gazdálkodással, a periodikus javítások tervezésével, az alkatrész-utánpótlás biztosításával,

\footnotetext{
${ }^{8}$ Re/976 A Mi-8 típusú helikopter légi üzemeltetési szakutasítása. Honvédelmi Minisztérium, 1980.

${ }^{9}$ Re/807 A Mi-24D típusú helikopter légi üzemeltetési szakutasítása. Honvédelmi Minisztérium, 1980.

${ }^{10}$ Continuing Airworthiness Management Organization.
} 
a helikopterek felszereltségének a különböző feladatokhoz történő hozzárendelésével. Ezeket a feladatokat a múltban részben az üzemeltetői, részben pedig az üzemben tartói szintre allokálták, mostanra azonban üzemeltetői feladatokká váltak. Ez a szervezet a gyár hazai kapcsolódási pontja: közvetlenül tárgyal a gyárral, rendel alkatrészeket, jelent be garanciális igényeket és igényel garanciális munkákat. A CAMO munkáját az MH Logisztikai Csoportfőnöksége mint üzemben tartó irányítja. A CAMO alárendeltségében dolgozik az üzemben tartó és karbantartó szervezet $\left(\mathrm{MRO}^{11}\right)$, amely két alegységre oszlik: az egyik a helikopterek napi földi kiszolgálását (Line Maintenace), a másik a karbantartást (Base Maintenance) biztosítja. Ezek a szervezeti elemek eddig is megvoltak, csak más elnevezéseik mellett ezeket a repülő-müszaki zászlóalj parancsnoka vezette.

A repülő-müszaki rendszer müködését egy minőségbiztosításban jártas szakember felügyeli, aki szoros együttmüködésben dolgozik az üzemben tartóval, a CAMO-val, az MRO-k vezetőivel és a helikopterbázis parancsnokával.

Az alkatrész-utánpótlás rendszere is átalakult. A múltban a fenntartó feladata volt a kapcsolattartás a gyárral. Ő kötött szerződéseket, az MH Logisztikai Központon keresztül ő szerzett be alkatrészeket és födarabokat, igényelt meg gyári szintü javításokat. Ezzel együtt a beérkező alkatrészek is csak az MH Anyagellátó Raktárbázison keresztül juthattak el az üzemeltető alakulathoz. Mint ahogy az elözőekben leírtam, jelenleg a CAMO tartja a kapcsolatot a gyárral és végzi azt a tevékenységet, melyet korábban a fenntartó. Mára a fenntartó irányítói szerepkörbe került. A CAMO által megrendelt alkatrész - sok esetben a DHL nemzetközi szállítmányozási vállalat által leszállítva - közvetlenül az alakulathoz kerül. A logisztikai rendszer müködése felgyorsult. Hozzá kellett szokni a gyár által biztosított 24 órás ügyfélszolgálat (Helpdesk) kihasználásához, az igénylést követő legfeljebb 48 órás alkatrész-beérkezési határidőkhöz. Mindezzel a papíralapú nyilvántartás idejétmúlttá vált, a folyamat müködtetése digitális platformra került.

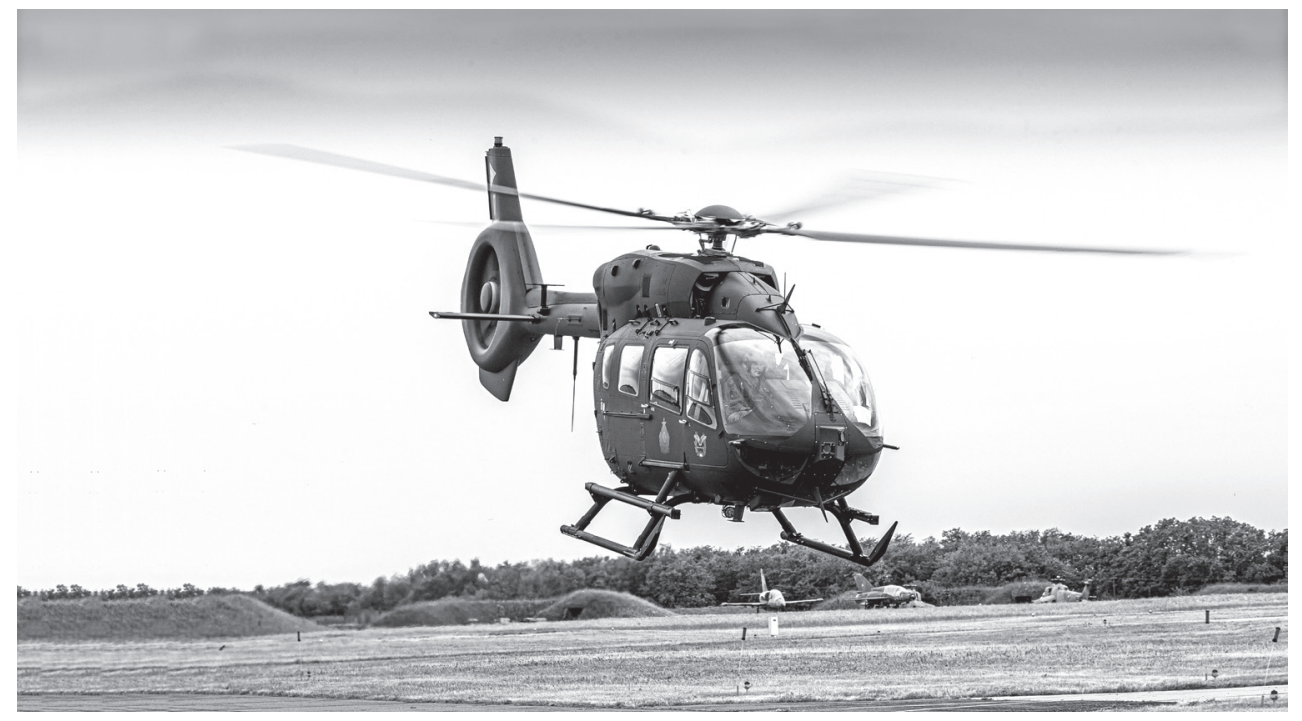

3. kép A H145M típusú könnyü helikopter

${ }^{11}$ Maintenance Repair Organization. 
Mindezek mellett a kiképzés is átalakult. A H145M rendszerbe állításával technológiai korszakváltás történt meg. Az eddig használt analóg müszerfallal rendelkező helikopterekről át kellett térnünk a digitális rendszerü légi jármüvek üzemeltetésére.

Ezekben a helikopterekben már nem találhatók mutatós kijelzők, a fedélzeti számítógépeknek köszönhetően pedig automatizálttá váltak azoknak a rendszereknek a földi és légi üzemeltetései, amelyeket eddig egy kifejezetten e célból a fedélzeten tartózkodó személy, a fedélzeti technikus végzett. Ha csak az indítási eljárást nézzük, akkor azt például a Mi-8 szállítóhelikopteren a háromfös gépszemélyzet 10-15 perc alatt teljesíti. A folyamat során szoros együttmüködésben kell pontról-pontra teljesíteniük az ötoldalas, A4 formátumú ellenőrzőlista pontjait. Ezzel ellentétben a H145M helikopter beindításához, illetve az összes fedélzeti rendszer leellenőrzéséhez 2-4 perc szükséges. Ezt egy fő teljesíti az egy A5-ös formátumú lap egyik oldalán leírt ellenőrzési pontok betartásával. Természetesen a repülés közbeni rendszerellenőrzési tevékenységeket is automatizálták, így lehetővé vált a helikopter egypilótás üzemeltetése. ${ }^{12}$

A számítógépes technológia a repülési stabilitás biztosításában is jelentős szerepet kapott. Ez fontos tényező, mivel egy helikopter a repülési tulajdonságait tekintve a hossz-, a kereszt- és a függőleges tengelye körül is a forgószárny és faroklégcsavar nyomatékai miatt eredendően instabil. A szovjet/orosz helikoptereknél - a kezdetleges stabilizációs rendszerek miatt - elképzelhetetlen, hogy a helikoptervezetö akár csak egy másodpercre is elengedje a légi jármü kezelöszerveit. A modern helikopterek a stabilizációs rendszereiknek köszönhetően már másfajta légi üzemeltetést igényelnek.

A folyamatos manuális irányítás helyét átveszi a fedélzeti számítógépek gyors problémamegoldó képessége, mely talán legkontrasztosabban a müszerrepülésnél nyilvánul meg. Eddig a müszerrepülés követelte a legösszetettebb repüléstechnikai készségeket. A kiképzési folyamatban korábban ennél a fázisnál mutatkozott a legnagyobb kihullási ráta. Mára ez a H145M-nél teljesen átalakult. Vészhelyzetnek minősül az, ha a helikoptervezető a kezelöszervekhez nyúl a müszerrepülés folyamán, mivel az Airbus filozófiája szerint egy jól beprogramozott számítógép sokkal pontosabban/precízebben vezeti a helikoptert, mint a helikoptervezető. Eljutottunk oda, hogy a bonyolult idős repülések minőségét és milyenségét a repülés előtti számítógép-programozás pontossága határozza meg. A megfelelő programozással elérhető, hogy a helikopter önállóan végrehajtsa a müszeres bejöveteli eljárást, illetve azután a felszállópálya felett három láb magasságban megfüggjön. Itt kell a helikoptervezetőnek először manuálisan beavatkoznia, vagyis gyakorlatilag $1 \mathrm{~m}$ magasról leszállnia. ${ }^{13}$

A helikopter fedélzeti vezérlőrendszere három pillérre támaszkodik: a Helionix rendszerre, a repüléstervező rendszerre $\left(\mathrm{FMS}^{14}\right)$ és a stabilizációs rendszerre $\left(\mathrm{AFCS}^{15}\right)$.

A Helionix biztosítja a hozzáférést a helikopter fedélzeti rendszereihez és a repüléshez szükséges információk lehívását (sebesség, magasság, függőleges emelkedés és süllyedés, irányszög, hajtómü és közlömú állapota, rendszerfelügyeleti adatok). Ebbe a rendszerbe vannak beágyazva a tereppel, illetve a más légi jármüvekkel történő összeütközésre figyelmeztető rendszerek. Az FMS integrálja a rádió- és mühold-navigációs eszközöket az UHF, ${ }^{16} \mathrm{VHF}^{17}$

\footnotetext{
12 BK117 D-2 (Helionix Step 2) Approved Rotorcraft Flight Manual. Airbus Helicopters Deutschland GmbH., 11. 12.2015

13 BK117 D-2 (Helionix Step 2) Approved Rotorcraft Flight Manual.

${ }^{14}$ Flight Management System.

15 Automatic Flight Control System.

16 Ultra High Frequency - $300 \mathrm{MHz}-3 \mathrm{GHz}$.

17 Very High Frequency - 30-300 MHz.
} 
és $\mathrm{HF}^{18}$ frekvenciasávokban üzemelni képes kommunikációs rendszerrel, a saját-idegen felismerőrendszerrel. A négyszintü stabilizációt biztosító AFCS teszi lehetővé a helikopter kiegyensúlyozott repülését.

Ezen pillérek együttmüködése/összekapcsolása - az Airbus terminológiájával Coupling egy időben határozza meg a helikopter müködését. A pillérek természetesen a fedélzeti számítógépek által vezérelve összekapcsolhatók és szétválaszthatók, azok szükség szerint kiiktathatók, illetve a repülés bármely pillanatában ismét aktivizálhatók. A Helionix funkciói repülés közben variálhatók. A fentebb leírt alapfunkcióin kívül lehetőség van digitális domborzati térkép megjelenítésére, külső kamerarendszeren keresztül történő megfigyelésre.

Mindezek figyelembevételével felmerülhet a kérdés: Miért van egyáltalán még pilóta a fedélzeten? A merevszárnyas repülésnél lassan ez már nem kérdés, a pilóta nélküli repülöeszközök alkalmazása dinamikusan növekszik. Más a helyzet a katonai forgószárnyasokkal, melyek döntően földközeli és terepkövetési magasságon repülnek. Ilyen magasságokon még technikailag nem megoldott a teljes autonómia. A természetes és a mesterséges akadályok elkerülése, az összeütközések megakadályozása egyelőre megköveteli a helikoptervezető manuális tevékenységét. Természetesen egy bizonyos, regionálisan biztonságos magasság felett itt is lehetséges a Helionix, az FMS és az AFCS összekapcsolása.

Az éjszakai repülések sem folytathatók az eddigi rendben. A H145M-en ezek elképzelhetetlenek az éjjellátó szemüveg $\left(\mathrm{NVG}^{19}\right)$ használata nélkül. Eddig a helikopteres repülések éjszaka vizuálisan történtek. Az NVG-s repülések a korlátozott mennyiségü éjjellátó eszköz, illetve az elérhető (Mi-8/17, Mi-24) helikopterek NVG-kompatibilis belső megvilágítási hiányosságai miatt csak egy szük kör számára volt lehetséges, és az is speciális kiképzést igényelt. Az Airbus rendszerben tekint az éjjellátó képességre, amit az éjjellátó képalkotó rendszer $\left(\mathrm{NVIS}^{20}\right)$ biztosít. Ebbe beletartoznak az NVG-k és az, hogy a helikopter belső világítása és müszerek háttérvilágítása a külső fényeivel NVG-kompatibilis. A helikopter infrareflektorral szerelt. Ezek mellett, ha a helikoptervezető éjjellátó berendezése meghibásodik és át kell térnie az éjszakai vizuális repülésre, akkor az vészhelyzetnek minősül. ${ }^{21}$

Látható, hogy a kiképzés átalakult, a repüléstechnikai képzés átformálása (NVG, müszerrepülés, navigáció) mellett hangsúlyozott irányként jelenik meg a számítógép repülés közbeni kezelése.

Hogyha azt analizáljuk, hogy honnan is adódik ez az óriási üzemeltetési filozófiai különbség - eltekintve a technológia fejlődésétől -, akkor megítélésem szerint kijelenthető, hogy az generációs okokra vezethető vissza. Míg a jelenleg használt helikoptereinket tervező mérnökök az 1930-as években születtek, ${ }^{22}$ addig a H145M mérnökei közel fél évszázaddal később. $^{23}$

\footnotetext{
${ }_{18}$ High Frequency - 3-30 MHz.

19 Night Vision Goggle.

${ }^{20}$ Night Vision Imaging System.

${ }^{21}$ BK117 D-2 (Helionix Step 2) Approved Rotorcraft Flight Manual.

22 A Mi-8 prototípusa 1961-ben készült el. Mil Mi-8. All the world's rotorcraft. http://www.aviastar.org/helicopters eng/mi-8.php; A Mi-24 rendszeresítése 1973-ban kezdődött a Német Demokratikus Köztársaságban települt szovjet erőknél. Mil Mi-24. All the world's rotorcraft. http://www.aviastar.org/helicopters_eng/mi-24.php (Letöltések időpontja: 2020. 10. 31.)

23 A H145M első változata - még EC145 néven - 2010-ben repült először. H145 Milestones from 2010 until Today. Planet - Helicopter. https://welt-der-hubschrauber.jimdofree.com/english/type-of-helicopters/h145/ (Letöltés időpontja: 2020. 10. 31.)
} 
Az eltelt időszak alatt a világ közel minden területen teljesen átalakult. A technikai fejlődéssel együtt az embereknek a világhoz való attitüdje is megváltozott. A problémák megoldását szolgáló eszközök tárháza kitárult, az információhoz, az adatokhoz és a kutatási eredményekhez való gyors hozzáférés rendszere kialakult, komplexebbé téve, de ezzel együtt leegyszerüsítve a mindennapok életét.

Ahogyan az 1950-es és az 1960-as évek szovjet mérnökei az akkori technológiai színvonalnak megfelelően fejlesztettek, úgy a mostani húszas, legfeljebb harmincas éveikben járó tervezők természetesen más (digitális) technológiára építve alakítják ki a helikoptereket. Az Airbus mérnökei a digitális világba születtek bele, a számítógépekkel együtt nőttek

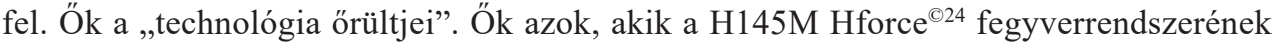
kezelésére a Sony Playstation kontrollert tervezik átalakítani. A digitális világ nélkül élni számukra a kőkorszakot jelenti.

Ezzel együtt a kiképzés szempontjából komoly nehézséget okoz az is, hogy a helikoptervezetőink 76\%-a az ún. X (1965-1979 között születettek), illetve a Baby Boomer (1947-1964) generációhoz tartozik. Egy részük számára a digitális eszközök használata kihívás jelent, mivel ők az ún. digitális bevándorlók, akik csupán csak beletanultak a digitális eszközök használatába. Számukra nehézséget jelent a $Z$ generáció által tervezett, számítógépek által vezérelt technológia ,zsigeri szintü” üzemeltetése.

Át kell alakítani az embereink gondolkodását ahhoz, hogy rá tudjunk hangolódni az új kihívásokra, hogy az analóg világból átléphessünk a digitális érába. Éppen ezért a Magyar Honvédség megvásárolta a helikoptervezetők, a repülő-müszakiak, de a fedélzeti rendszerkezelők képzését is az Airbus Helicopters cégtől. A gyári átképzés mellett szintén megrendeltük az úgynevezett „,On-the-job training” elnevezésü képzési lehetőséget, melynek keretében helikoptervezető- és repülö-müszaki oktatók/mentorok felügyelik Szolnokon a hazai szakemberek munkáját. A helikopterbázison ők segítik azoknak az embereinknek a földi és légi üzemeltető tevékenységét, akik már teljesítették a típusátképzésüket az Airbus donauwörthi és ingolstadti kiképzési központjaiban.

\section{BEFEJEZÉS}

A fenti tanulmányban igyekeztem plasztikusan összegezni azokat a képességformáló összetevőket, amelyek a címben is megfogalmazott kultúraváltáshoz vezettek. Részletesen írtam a kiképzés átalakításának kérdéseiről, a megoldott logisztikai és infrastrukturális kihívásokról, a szükségszerüen átalakított állománytábláról.

Emellett azonban nem tértem ki több területre. Csak érintettem például a HForce ${ }^{\odot}$ fegyverrendszert, és nem említettem a H145M felderítőrendszerét sem. Ezek háttérbe szorultak, de nem csupán azért, mert az információk azokról nagyrészt minősítettek, hanem azért is, mert ezeknek az eszközöknek az alkalmazása, illetve az azokra történő felkészítés még elöttünk áll.

Nyilvánvaló, hogy a H145M helikopternek a hazai helikopteres erők életébe 2021 végére tervezett teljes integrálásáig még hosszú utat szükséges bejárni. Első lépésben az egyéni szakkiképzés során elsajátított ismereteket készségszintre kell begyakorolni - kötelékkiképzési rendben - hazai körülmények között, együttmüködve a szárazföldi haderőnemmel. Második

\footnotetext{
${ }^{24}$ Az Airbus HForce ${ }^{\circ}$ rendszere konténerekben függesztett irányítható és nem irányítható rakétákat, illetve gépágyút foglal magában. https://www.airbus.com/helicopters/military-helicopters/hforce.html (Letöltés időpontja: 2020. 10.31.)
} 
lépésben meg kell jelenni olyan nemzetközi gyakorlatokon, ahol a német haderő H145M helikoptereivel közösen tudunk majd például különleges müveleti feladatokat többnemzeti kötelékben begyakorolni.

\section{FELHASZNÁLT IRODALOM}

Airbus-honlap. https:/www.airbus.com/helicopters/military-helicopters/hforce.html

BK117 D-2 (Helionix Step 2) Approved Rotorcraft Flight Manual. Airbus Helicopters Deutschland GmbH., 11. 12. 2015.

H145 Milestones from 2010 until Today. Planet - Helicopter. https://welt-der-hubschrauber.jimdofree. com/english/type-of-helicopters/h145/

Hungary orders 16 H225M multi-role helicopters. Airbus Media, 14. 12. 2018. https://www.airbus. com/newsroom/press-releases/en/2018/12/hungary-orders-16-h225m-multi-role-helicopters.html

Hungary orders 20 H145Ms. Airbus Media, 29. 06. 2018. https://www.airbus.com/newsroom/pressreleases/en/2018/06/hungary-orders-20-h145ms-.html

Mil Mi-8. All the world's rotorcraft. http://www.aviastar.org/helicopters_eng/mi-8.php

Mil Mi-24. All the world's rotorcraft. http://www.aviastar.org/helicopters_eng/mi-24.php

Re/390 Mi-24D Helikopter Harckiképzési Szakutasítása. Honvédelmi Minisztérium, 1977.

Re/807 A Mi-24D típusú helikopter légi üzemeltetési szakutasítása. Honvédelmi Minisztérium, 1980.

Re/976 A Mi-8 típusú helikopter légi üzemeltetési szakutasítása. Honvédelmi Minisztérium, 1980.

Re/1320 Mi-8/17 Helikopter Harckiképzési Szakutasítás. Honvédelmi Minisztérium, 1981.

Simicskó: indul a Zrínyi 2026 program. BOON, 2016. 12. 20. https://boon.hu/helyi-kozelet/simicskoindul-a-zrinyi-2026-program-2615932/ 